\author{
Monika Papież \\ Stawomir Śmiech \\ Marek A. Dąbrowski
}

\title{
THE IMPACT OF THE EURO AREA MACROECONOMY ON GLOBAL COMMODITY PRICES*
}

\begin{abstract}
The aim of this paper is to analyse the links between real and financial processes in the euro area and energy and non-energy commodity prices. Monthly data spanning 1997:1 to 2013:12 and the structural VAR model are used to uncover the relationship between global commodity prices and the euro area economy. The analysis is performed for three sub-periods in order to capture potential changes in this relationship over time. The main finding is that commodity prices in the euro area do not respond to impulses from production (economic activity), whereas commodity prices strongly react to impulses from financial processes, i.e. interest rates in the euro area and the exchange rate of the dollar against the euro, especially in the run-up to the global financial crisis. The study also provides evidence of a tightening relationship between energy and non-energy commodity prices.
\end{abstract}

Keywords: commodity prices, real economy, financial market, structural vector autoregression model.

JEL Classification: E44, C3, E37, E47, Q17, Q43.

Monika Papież, Cracow University of Economics, Department of Statistics, Rakowicka 27, 31-510

Kraków, Poland, e-mail address: monika.papiez@uek.krakow.pl.

Sławomir Śmiech, Cracow University of Economics, Department of Statistics, Rakowicka 27, 31-510 Kraków, Poland, e-mail address: slawomir.smiech@uek.krakow.pl.

Marek A. Dąbrowski, Cracow University of Economics, Department of Macroeconomics, Rakowicka 27, 31-510 Kraków, Poland, e-mail address: marek.dabrowski@uek.krakow.pl.

* Supported by grant No. 2012/07/B/HS4/00700 of the Polish National Science Centre. A draft of this paper was presented at the International Interdisciplinary Business-Economics Advancement Conference (IIBA 2014) in Istanbul and at the eighth Professor Aleksander Zeliaś International Conference on the Modelling and Forecasting of Socio-Economic Phenomena in Zakopane in 2014. We thank the conference participants for their helpful comments. 


\section{Introduction}

The prices of energy and non-energy sources play a key role in economic development. High commodity prices can make production unprofitable and steer the economy into a crisis. This threat is particularly acute in countries and regions that have no resources of their own and so must import raw materials. The problem is exacerbated by the tendency of commodity prices to co-move. Many theories and hypotheses have been advanced to explain the co-movement of commodity prices. The most general interpretation is that it is a response to common, global macroeconomic shocks. The problem is that fluctuations in commodity prices are disproportionate in relation to the fundamental variables. Pindyck and Rotemberg (1990) attribute this excess co-movement to the herd behaviour of investors. In this situation changes in overall price indexes can trigger price movements in any commodity because traders are alternatively in either long or short positions on all commodities for no plausible economic reason. Lescaroux (2009) extends this analysis by taking into account inventory levels for oil and metal prices. Frankel and Rose (2010) refer to four plausible theories of the co-movement of commodity prices: strong global growth, especially in China and India (oil prices are studied in this context by Kilian 2008, 2009a, 2009b; Hamilton 2009; Kaufmann 2011), easy monetary policy and low real interest rates (Frankel 2008; Kilian 2010), speculation (Davidson 2008; Krugman 2008; Śmiech \& Papież 2013; Parsons 2010) and the risk resulting from potential geopolitical uncertainties. Sari et al. (2010) point out that oil and precious metals are denominated in US dollars and therefore co-move. The negative relationship between the value of the dollar and dollar denominated commodities follows from the law of one price for tradeable goods. The tendency of investors to stay long in raw materials rather than assets when a period of inflation is expected may be another explanation for co-movement. Akram (2009), who also finds evidence that a weaker dollar leads to higher commodity prices, and that interest rate reductions cause excessive price increases in oil and industrial raw materials, draws a similar conclusion. Different results are obtained by Frankel and Rose (2010) and Alquist et al. (2011), who find no statistically significant relationships between real interest rates and oil prices.

This study aims to answer the following question: Are commodity prices related to real and financial processes in the euro area macroeconomy? There are several reasons why we focus on the link between global commodity prices and the euro area economy. First, the euro area was 
selected for the research because it is the world's second largest economy. It had a GDP of approximately USD 12,700 billion in 2013 compared to GDP in the USA in the same year of approximately USD 16,800 billion. Second, the euro area countries have insufficient energy resources, which is why the share of imported fossil fuels in total energy consumption is so high (60\% for the EU in 2009) and continues to grow. Finally, to the best of our knowledge, no study has yet been produced on the relationships between the euro area macroeconomy and global commodity prices.

The analysis is based on monthly data covering January 1997-December 2013. The real processes of the euro area are represented by industrial production, while the financial conditions are represented by interest rates. Bearing in mind the significant role of the United States dollar (USD), we adopted the USD/EUR exchange rate for the purposes of the study. Commodity prices are represented by the energy price index and non-energy price index published by the World Bank database. The structural VAR model is used to investigate the relationships as it enables them to be interpreted in economic terms. We use a standard recursive structure obtained by a Choleski decomposition to identify structural shocks (Akram 2009). The analysis is conducted in three non-overlapping sub-periods: January 1997-December 2002, January 2003-December 2008, and January 2009-December 2013. The division of the sample period into three sub-periods makes it possible to test the stability of the relationships investigated and the influence of real and financial processes in the euro area economy on commodity prices. It also makes it possible to analyse the changes in relationships between energy commodity prices and non-energy commodity prices and to take account of the growing share of biofuels in euro-area energy consumption. We should note that biofuels belong to the non-energy index.

The major finding is that commodity prices in the euro area do not respond to impulses from production (economic activity). At the same time, commodity prices react strongly to impulses from financial processes, such as euro-area interest rates and the USD/EUR exchange rate (especially in the period before the global financial crisis). The study also reveals the tightening of the relationship between energy and non-energy commodity prices.

We now move to Section 2, which briefly presents the methodology used in the study. The data are then described in Section 3. Section 4 contains the empirical results. Our final conclusions are presented in the last section. 


\section{Methodology}

The empirical analysis is based on structural vector autoregression (SVAR) models proposed by Sims (1980). Two types of SVAR models are developed. The first is derived from the Blanchard and Quah (1989) model and assumes long-term restrictions to innovations using the economic theory. The second is known as an AB model (Breitung et al. 2004) and deals with short-term restrictions. The study employs the latter:

$$
A y_{t}=A_{1} y_{t-1}+A_{2} y_{t-2}+\ldots+A_{p} y_{t-p}+B \varepsilon_{t},
$$

where: $y_{t}$ contains the vector of variables, $\varepsilon_{t} \sim\left(0, I_{k}\right) ; A$ is a $k \times k$ invertible matrix of structural coefficients, which describes the contemporaneous relationships between the variables in $y_{t} ; A_{i}(i=1,2, \ldots, p)$ are $k \times k$ coefficient matrices describing dynamic interactions between the $k$-variables; and $B$ is a $(k \times k)$ matrix of structural coefficients representing the effects of $k$ structural shocks. The reduced form of equation (1) can be obtained by pre-multiplying with the inverse of $A$ :

$$
y_{t}=A^{*}{ }_{1} y_{t-1}+A^{*} y_{t-2}+\ldots+A_{p}^{*} y_{t-p}+u_{t},
$$

where: $A_{i}^{*}=A^{-1} A_{i}, u_{t}=A^{-1} B \varepsilon_{t}$, and $u_{t} \sim\left(0, \sum_{u}\right)$ is the symmetric variance-covariance matrix of the reduced form consisting of $k(k+1) / 2$ elements.

The reduced form model is difficult to understand without reference to a specific economic structure, and its parameters have no economic interpretations. In the case of structural models, identification focuses on the (orthogonal) errors of the system, which are interpreted as exogenous shocks. The structural VAR model (1) can be estimated based on the reduced form model (2) which, however, has fewer parameters. In this way at least $k^{2}+k(k-1) / 2$ restrictions of the matrices $A$ and $B$ must be imposed to identify model (1) (Breitung et al. 2004). Most applications therefore consider special cases with $A=I_{k}$ (B models) or $B=I_{k}$ (A models). The necessary restrictions can be obtained from economic theory or from atheoretical rules, such as the "timing scheme" for shocks proposed by Sims (1980).

Impulse response analysis can be employed to analyse the dynamic interactions between the endogenous variables of VAR(p) models. Assuming that model (1) represents stationary $(\mathrm{I}(0))$ process $y_{t}$, it has a Wold's moving average (MA) representation:

$$
y_{t}=\Phi_{0} u_{t}+\Phi_{1} u_{t-1}+\Phi_{2} u_{t-2}+\ldots
$$


where $\Phi_{0}=I_{K}$ and $\Phi_{s}$ are computed recursively. The $(i, j)$ element of the matrix $\Phi_{s}$, considered as a function of $s$, measures the expected response of $y_{i, t+s}$ to a unit change in innovations $u_{j, t}$. The variance decomposition of forecast errors is another useful interpretation of the SVAR model. To obtain it, it is sufficient to notice, using (3), that forecast variance $y_{T+s}$ is expressed as:

$$
\sum_{s}=\operatorname{Var}\left(y_{T+s}\right)=\sum_{m=0}^{s-1} \Phi_{m} \Phi_{m}^{\prime} .
$$

The diagonal element of $\sum_{s}$ describes the variance of forecast error as the sum of the errors resulting from individual structural shocks.

\section{Data}

The relationships between commodity prices, the real economy and financial indicators in the euro area are explored by reference to monthly data from the period January 1997-December 2013. The analysis is based on five series of variables. The first is the industrial production index (IP) in the euro area, which describes the real economy in Europe. The second is the three-month euro-area interest rate (IR), which describes the financial economy. The data for both variables are taken from the Eurostat database. The third variable is the real exchange rate (REX). The remaining two variables are the commodity price indexes, that is, the energy price index (PEN) and the non-energy commodity price index (PNEN). The data for these variables are taken from the World Bank database. The energy price index (world trade-base weights) consists of crude oil (84.6\%), natural gas $(10.8 \%)$ and coal $(4.6 \%)$. The non-energy price index consists of metals (31.6\%), fertilisers (3.6\%) and agriculture (64.8\%). A detailed description of the variables is provided in Table 1 , and basic descriptive statistics can be found in Table 2. All of the series are then expressed as indices (so that their average values in 2010 are equal to 100), seasonally adjusted and specified in natural logarithms.

The sample period is divided into three sub-periods. The first covers January 1997-December 2002, the second January 2003-December 2008 and the third January 2009-December 2013. The first, January 1997December 2002, contains 72 observations. With a mean value of 96.41, the industrial production index - and euro area economic activity - is at its lowest in this period. The prices of energy sources and non-energy sources are also at their lowest in this period, while interest rates are at their highest 
with a mean of 1.99 and a median of 2.20 . The energy price index increases by $5.5 \%$ and the non-energy price index decreases by $29.2 \%$ in the first sub-period.

Table 1. The Dataset - Description of Variables

\begin{tabular}{|c|c|c|c|}
\hline Variable & Full name & Description & Source \\
\hline$I P$ & $\begin{array}{l}\text { the industrial } \\
\text { production } \\
\text { index in the euro } \\
\text { area }\end{array}$ & $\begin{array}{l}\text { euro area } 17 \text { (fixed composition) - Industrial } \\
\text { Production Index, Total Industry (excluding } \\
\text { construction) - NACE Rev2; Eurostat; } \\
\text { Working day and seasonally adjusted }\end{array}$ & Eurostat \\
\hline$I R$ & $\begin{array}{l}\text { the three-month } \\
\text { interest rate } \\
\text { in the euro area }\end{array}$ & $\begin{array}{l}\text { nominal interest rate }(\mathrm{NIR}) \text { minus HICP } \\
\text { inflation: } \\
100\left[\ln \left(1+N I R_{t}\right)-\left(\ln H I C P_{t}-\ln H I C P_{t-12}\right)\right]\end{array}$ & Eurostat \\
\hline$R E X$ & $\begin{array}{l}\text { the real } \\
\text { exchange rate }\end{array}$ & $\begin{array}{l}\text { index of nominal exchange rate (end of } \\
\text { month), NER, adjusted by consumer price } \\
\text { indexes in the US and euro area: } \\
100 \cdot N E R \cdot C P I_{U S} / H I C P_{E A}, 2010=100\end{array}$ & $\begin{array}{l}\text { Eurostat, } \\
\text { Federal } \\
\text { Reserve Bank } \\
\text { of St Louis }\end{array}$ \\
\hline PEN & $\begin{array}{l}\text { the energy } \\
\text { price index }\end{array}$ & $\begin{array}{l}\text { monthly index based on nominal US dollars } \\
\text { deflated with CPIUS, } 2010=100\end{array}$ & $\begin{array}{l}\text { World Bank, } \\
\text { Federal } \\
\text { Reserve Bank } \\
\text { of St Louis }\end{array}$ \\
\hline PNEN & $\begin{array}{l}\text { the non-energy } \\
\text { price index }\end{array}$ & $\begin{array}{l}\text { monthly index based on nominal US dollars } \\
\text { deflated with CPIUS, } 2010=100\end{array}$ & $\begin{array}{l}\text { World Bank, } \\
\text { Federal } \\
\text { Reserve Bank } \\
\text { of St Louis }\end{array}$ \\
\hline
\end{tabular}

Source: authors' own compilation.

Table 2. Descriptive Statistics

\begin{tabular}{l|c|c|c|c|c}
\hline & $I P$ & $I R$ & $R E X$ & $P E N$ & $P N E N$ \\
\hline Mean & 100.60 & 0.73 & 109.60 & 75.20 & 77.65 \\
\hline Median & 100.46 & 0.93 & 104.84 & 70.01 & 73.38 \\
\hline Maximum & 114.68 & 2.99 & 152.58 & 175.64 & 127.20 \\
\hline Minimum & 87.45 & -2.32 & 83.77 & 20.16 & 47.54 \\
\hline Std. Dev. & 5.79 & 1.42 & 16.34 & 37.05 & 22.05 \\
\hline Skewness & 0.29 & -0.31 & 0.99 & 0.35 & 0.47 \\
\hline Kurtosis & 2.97 & 2.01 & 3.14 & 2.05 & 1.99 \\
\hline
\end{tabular}

Source: authors' own calculations.

The second sub-period, January 2003-December 2008, contains 72 observations. The energy price index increases by $28.5 \%$ and the non- 
-energy price index increases by $32.2 \%$ in this period. The euro zone economy is then at its most active, which is demonstrated by the highest values for the industrial production index, which has a mean value of 105.68. With a mean of 0.72 and a median of 0.36 , the interest rates are lower than in the first period.

In the final sub-period, January 2009-December 2013, the mean and the median of the real interest rates are negative at -0.84 and -1.05 respectively. The values displayed by the industrial production index, whose mean value is 99.55 , are only slightly higher than in the first sub-period, and much lower than in the second sub-period. The energy price index increases by $78.4 \%$ and the non-energy price index increases by $16.5 \%$ in the final sub-period.

\section{Empirical Results}

\subsection{Time Series Properties of the Data}

A preliminary analysis of the series is carried out before estimating the main model. The standard augmented ADF unit root tests (Dickey \& Fuller 1979) for both the intercept and the trend specifications demonstrate that all of the variables have unit roots for each sub-period analysed. The number of lags in the test is established using the AIC criterion. The ADF unit root test confirmed that all of the variables are integrated of an order of one, i.e. I(1), thus making the test for cointegration justified. The test results are presented in Table 3.

Table 3. Unit Root Test Results for each Sub-period

\begin{tabular}{c|c|c|c|c|c}
\hline \multirow{2}{*}{ Sub-period } & \multirow{2}{*}{ Variable } & \multicolumn{2}{|c|}{ Level } & \multicolumn{2}{c}{ First difference } \\
\cline { 3 - 6 } & intercept & $\begin{array}{c}\text { intercept and } \\
\text { trend }\end{array}$ & intercept & $\begin{array}{c}\text { intercept } \\
\text { and trend }\end{array}$ \\
\hline 1997:1-2002:12 & $I P$ & -2.7232 & -1.6266 & $-11.6381^{* * *}$ & $-12.1336^{* * *}$ \\
\cline { 2 - 6 } & $I R$ & -0.6207 & -2.5671 & $-7.3601^{* * *}$ & $-7.3496^{* * *}$ \\
\cline { 2 - 6 } & $R E X$ & -1.4755 & -0.1782 & $-7.0423^{* * *}$ & $-7.2472^{* * *}$ \\
\cline { 2 - 6 } & $P E N$ & -1.3676 & -1.5073 & $-6.0474^{* * *}$ & $-5.9651^{* * *}$ \\
\cline { 2 - 6 } & $P N E N$ & -0.9121 & -1.3533 & $-7.4002^{* * *}$ & $-7.3506^{* * *}$ \\
\hline 2003:1-2008:12 & $I P$ & -1.1568 & -1.0029 & $-11.9064^{* * *}$ & $-11.9143^{* * *}$ \\
\cline { 2 - 6 } & $I R$ & -1.0186 & -1.8155 & $-7.4128^{* * *}$ & $-7.3509^{* * *}$ \\
\cline { 2 - 6 } & $R E X$ & -2.3057 & -2.4251 & $-8.4422^{* * *}$ & $-8.4539^{* * * *}$ \\
\cline { 2 - 6 } & $P E N$ & -1.1136 & -2.0591 & $-8.4195^{* * *}$ & $-8.3045^{* * *}$ \\
\cline { 2 - 6 } & $P N E N$ & -0.5708 & -2.7851 & $-8.6750^{* * *}$ & $-8.5870^{* * *}$ \\
\hline
\end{tabular}


Table 3 cnt'd

\begin{tabular}{c|c|c|c|c|c}
\hline \multirow{2}{*}{ Sub-period } & \multirow{2}{*}{ Variable } & \multicolumn{2}{|c|}{ Level } & \multicolumn{2}{c}{ First difference } \\
\cline { 3 - 6 } & & intercept & $\begin{array}{c}\text { intercept and } \\
\text { trend }\end{array}$ & intercept & $\begin{array}{c}\text { intercept } \\
\text { and trend }\end{array}$ \\
\hline \multirow{2}{*}{ 2009:1-2013:12 } & $I P$ & -2.3250 & -2.3984 & $-4.1896^{* * *}$ & $-4.0177^{* * *}$ \\
\cline { 2 - 6 } & $I R$ & -2.4061 & -1.0401 & $-6.9393^{* * *}$ & $-7.4423^{* * *}$ \\
\cline { 2 - 6 } & REX & -2.5147 & -2.7323 & $-8.5349^{* * *}$ & $-8.4427^{* * *}$ \\
\cline { 2 - 6 } & $P E N$ & -2.2888 & -1.3825 & $-12.8698^{* * *}$ & $-13.1621^{* * *}$ \\
\cline { 2 - 6 } & $P N E N$ & -2.2941 & -0.5975 & $-11.2026^{* * *}$ & $-12.2130^{* * *}$ \\
\hline
\end{tabular}

Note: All variables in natural logs, lag lengths are determined via AIC; $\left({ }^{* * *}\right)$ indicates the rejection of unit root at $1 \%$.

Source: authors' own calculations.

Table 4. Test for Cointegration (with Intercept in the CE) for each Sub-period

\begin{tabular}{c|c|c|c|c|c}
\hline \multirow{2}{*}{ Sub-period } & \multirow{2}{*}{$\begin{array}{c}\text { Hypothesised } \\
\text { no. of CE(s) }\end{array}$} & \multicolumn{2}{|c|}{ Trace statistic } & \multicolumn{2}{c}{ Max-Eigenvalue statistic } \\
\cline { 3 - 6 } & $\begin{array}{c}\text { test } \\
\text { statistic }\end{array}$ & $\begin{array}{c}\text { critical value } \\
0.05\end{array}$ & $\begin{array}{c}\text { test } \\
\text { statistic }\end{array}$ & $\begin{array}{c}\text { critical value } \\
0.05\end{array}$ \\
\hline 1997:1-2002:12 & none & 68.040 & 69.819 & 26.663 & 33.877 \\
\cline { 2 - 6 } & at most 1 & 41.377 & 47.856 & 19.853 & 27.584 \\
\cline { 2 - 6 } & at most 2 & 21.523 & 29.797 & 16.327 & 21.132 \\
\cline { 2 - 6 } & at most 3 & 5.196 & 15.495 & 3.927 & 14.265 \\
\cline { 2 - 6 } & at most 4 & 1.269 & 3.841 & 1.269 & 3.841 \\
\hline 2003:1-2008:12 & none & $70.654^{* *}$ & 69.819 & 33.429 & 33.877 \\
\cline { 2 - 6 } & at most 1 & 37.224 & 47.856 & 19.530 & 27.584 \\
\cline { 2 - 6 } & at most 2 & 17.694 & 29.797 & 9.473 & 21.132 \\
\cline { 2 - 6 } & at most 3 & 8.221 & 15.495 & 7.321 & 14.265 \\
\cline { 2 - 6 } & at most 4 & 0.899 & 3.841 & 0.899 & 3.841 \\
\hline 2009:1-2013:12 & none & 69.481 & 69.819 & 27.062 & 33.877 \\
\cline { 2 - 6 } & at most 1 & 42.418 & 47.856 & 21.293 & 27.584 \\
\cline { 2 - 6 } & at most 2 & 21.125 & 29.797 & 12.239 & 21.132 \\
\cline { 2 - 6 } & at most 3 & 8.886 & 15.495 & 8.740 & 14.265 \\
\cline { 2 - 6 } & at most 4 & 0.147 & 3.841 & 0.147 & 3.841 \\
\hline
\end{tabular}

Note: $(* *)$ indicates statistical significance at the $5 \%$ level.

Source: authors' own calculations.

The investigation then turns to the presence of a long-term relationship between the integrated variables. The trace test statistic 
proposed by Johansen and Juselius (1990) is employed to detect this relationship. If the variables are cointegrated, which suggests a long-term relationship, simply differencing them is inappropriate and will result in a misspecification. Table 4 presents the results of the Johansen cointegration test. The Johansen maximum likelihood approach, which employs both maximum eigenvalue and trace statistics, is used to test cointegration. While no cointegration at the $5 \%$ level is detected in the first and third sub-periods the test does find evidence of cointegration in the second sub-period. The trace test indicates a single cointegrating equation at the 0.05 level. In contrast, the maximum eigenvalue test indicates no cointegration at the 0.05 level $^{1}$. Since the results of the cointegration tests are at best ambiguous and at worst suggest no cointegration whatsoever, and the variables are integrated of an order of one I(1), we employ a VAR for the first differences in our five variables.

The number of VAR lags for each sub-period is established using the AIC criterion. The lag length is one for the first and second sub-periods and two for the third sub-period.

\subsection{Structural Impulse Response Analysis}

We employ the Choleski decomposition of the reduced form and assume that $A$ is an identity matrix, while $B$ is a lower triangular matrix, to identify the SVAR model. To identify the shocks, we order the variables in the VAR models, and thereby the corresponding shocks $(\triangle I P, \triangle I R, \triangle R E X, \triangle P E N$, $\triangle P N E N)$.

$$
B \varepsilon=\left[\begin{array}{ccccc}
* & 0 & 0 & 0 & 0 \\
* & * & 0 & 0 & 0 \\
* & * & * & 0 & 0 \\
* & * & * & 0 \\
* & * & * & *
\end{array}\right]\left[\begin{array}{l}
\varepsilon_{I P} \\
\varepsilon_{I R} \\
\varepsilon_{R E X} \\
\varepsilon_{P E N} \\
\varepsilon_{P N E N}
\end{array}\right],
$$

where: $B$ is a lower diagonal matrix consistent with the Choleski decomposition, the "*" entries in the matrix represent unrestricted parameter values and the zeroes suggest that the associated fundamental shock does not contemporaneously affect the corresponding endogenous variable.

${ }^{1}$ Since the sample was short, and there were five series in a vector of interests, a Monte Carlo experiment was performed and the empirical critical values of the trace test were determined. Following the test, we found that the null hypothesis of no cointegration was rejected too often. 
A five-variable VAR is estimated for changes in industrial production $(\triangle I P)$, the real interest rate $(\triangle I R)$, the real exchange rate $(\triangle R E X)$, the real energy price index $(\triangle P E N)$ and the real non-energy price index $(\triangle P N E N)$. The ordering of variables is implied by economic theory and the objective of this study, which is to capture the reactions of commodity prices to all of the other variables. It is for this reason that the commodity prices are placed at the end. A similar ordering is applied by Akram (2009). Because it adjusts sluggishly to shocks, industrial production is supposed to be the least responsive variable, which is why it is selected as the first variable in the VAR. The decision to position the interest rate before the exchange rate, which is nevertheless in accord with the ordering applied by Arora and Tanner (2013), is of secondary importance since the focus falls on commodity prices.

The impulse response results for structural, one-standard deviation innovations in the industrial production index, the real interest rate, the real exchange rate, the energy price index and the non-energy price index are illustrated in Figures 1-3 for each sub-period respectively. For example, the impulse response of each variable in the system to an innovation in the industrial production index in the first sub-period is shown in the first column of Figure 1 with a solid line. The dashed lines correspond to plus or minus two standard errors around the impulse responses.

The output shocks in the sub-period January 1997-December 2002 were mostly neutral for all variables except the real interest rate. The latter's response was consistent with our intuition: as the economy expanded driven by the positive production shock, the interest rate increased. Since positive shocks can trigger inflation, this might also have been accompanied by changes in the policy rate.

Shocks to the real interest rate prompted a negative reaction from the energy price index, which is consistent with Hotelling's rule, which states that the gain made from storing a commodity should be equal to the interest rate. The gain includes a revaluation gain and a convenience yield and is adjusted downwards by storage cost and risk premium (see Frankel \& Rose 2010 or Śmiech et al. 2014). That energy prices react in this way to the interest rate demonstrates their similarity to asset prices (Svensson 2008).

The real depreciation of the United States dollar exerts a positive impact on both commodity prices, which is a connection that has been identified by other scholars, such as Akram (2009). This can be explained as follows: if commodity prices are quoted in United States dollars, which they are, and this currency depreciates, commodity prices will fall when they are expressed 

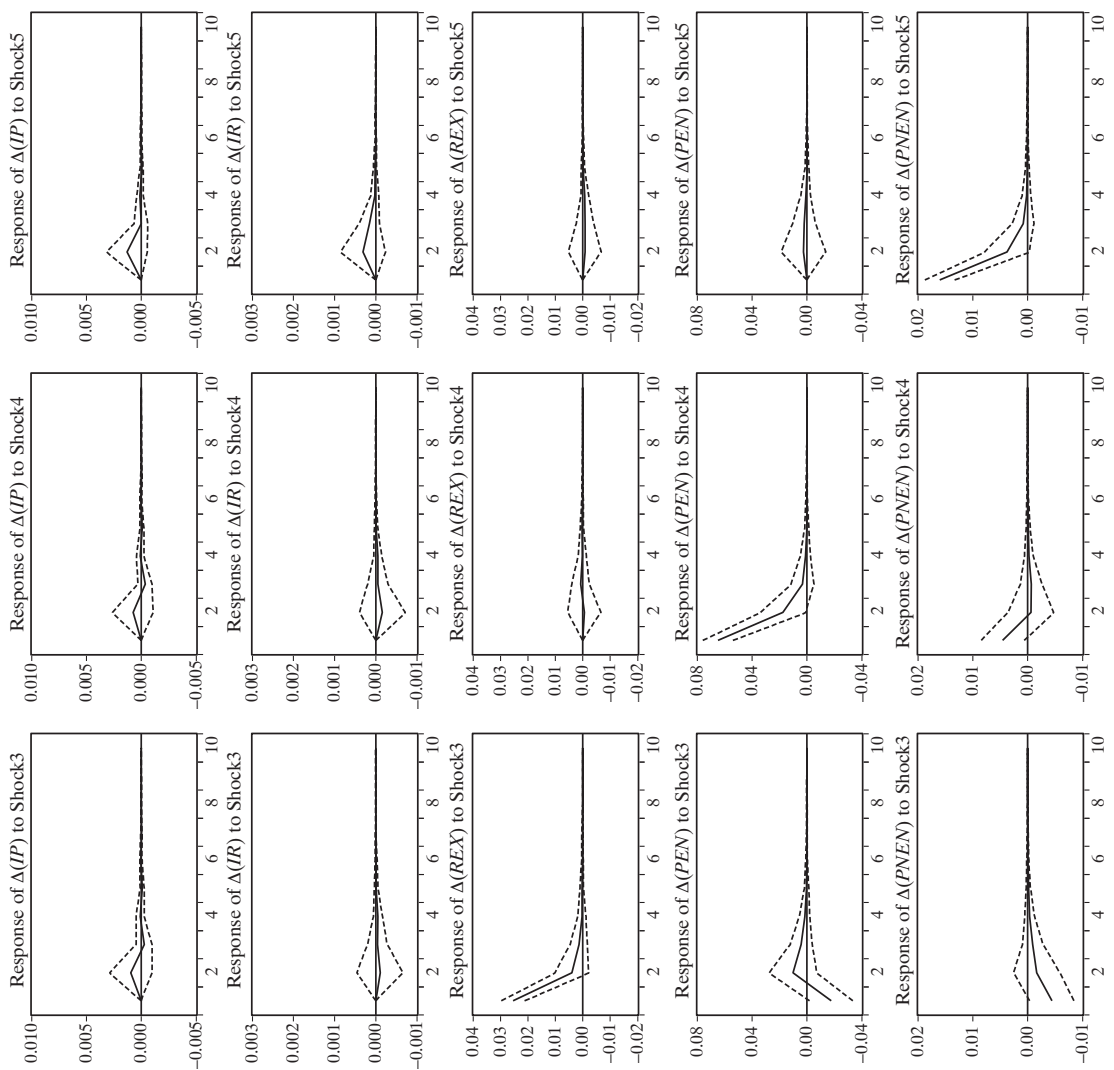

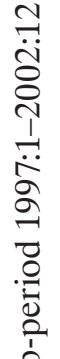
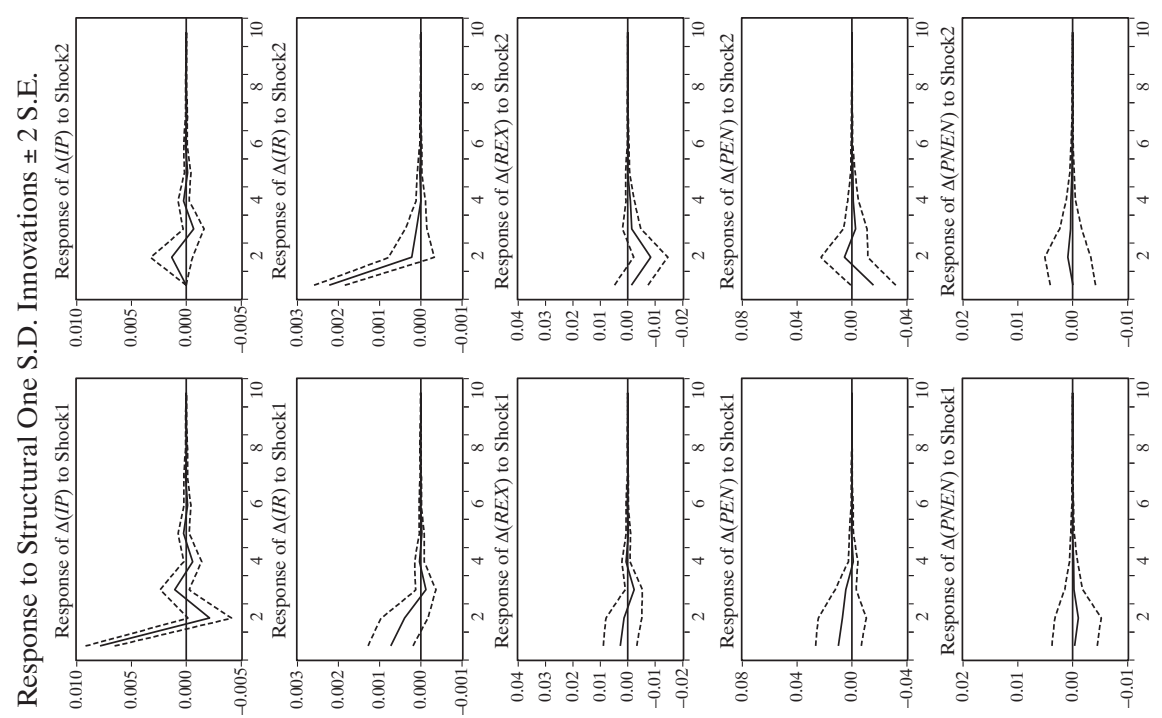

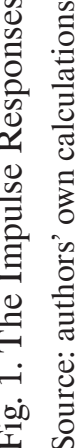


70 Monika Papież, Sławomir Śmiech, Marek A. Dąbrowski
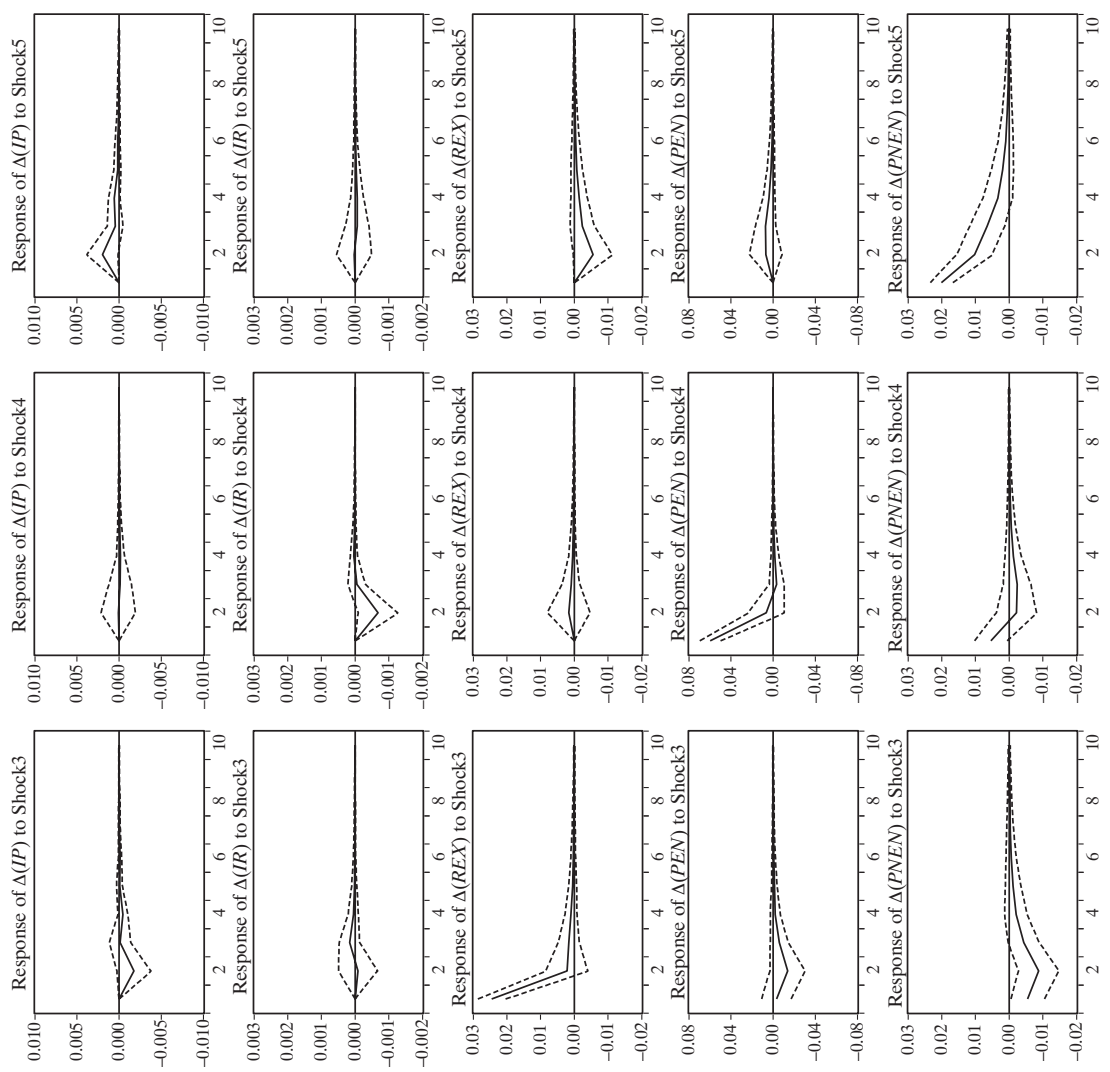

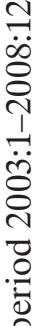
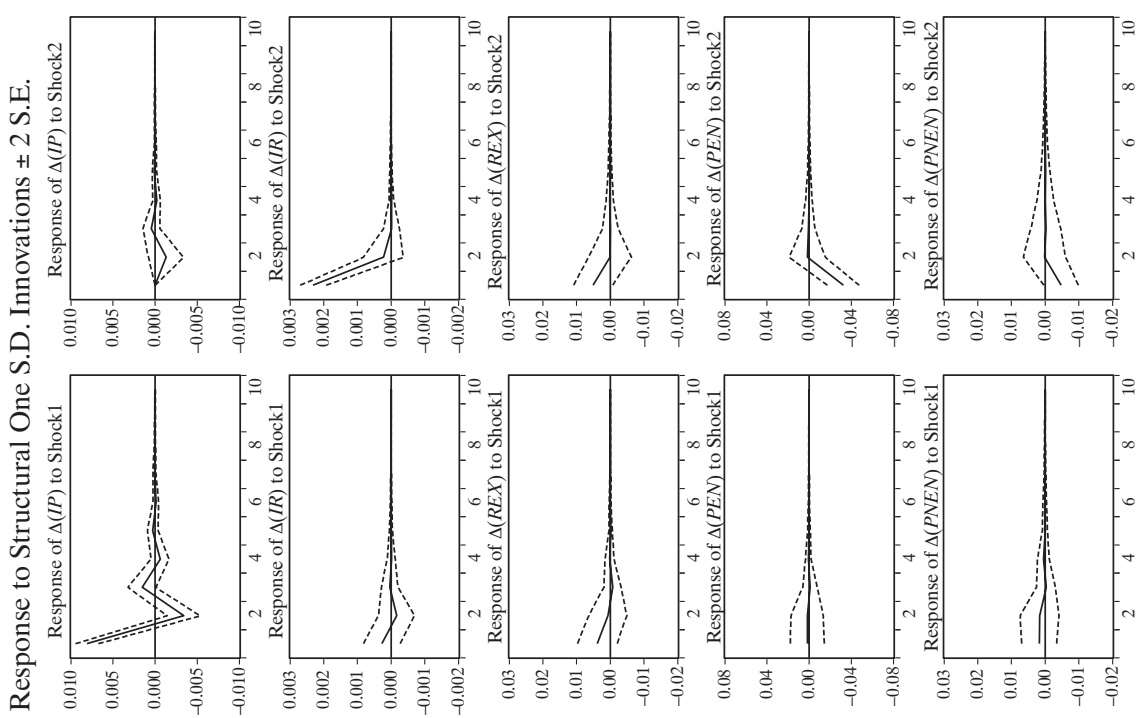

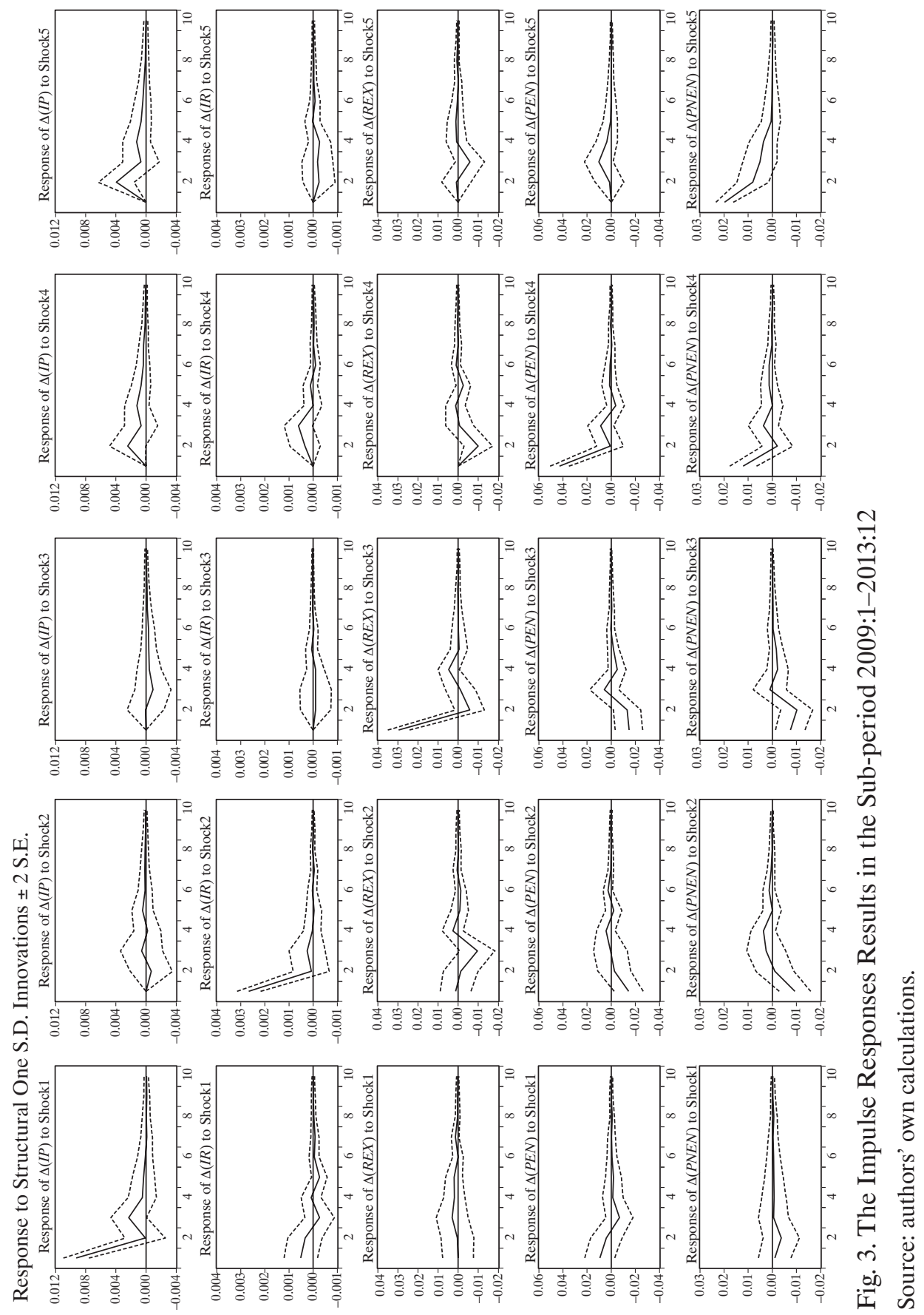
in other currencies. The demand for commodities will then increase, which results in a higher dollar price for commodities and some reversal of the initial depreciation of the United States dollar.

The non-energy price index makes a significant and positive response to shocks in energy prices. Both commodities could thus be seen as related to each other. In other words, non-energy prices could not deviate too much from energy prices.

Figure 2 illustrates the impulse response functions for the January 2003-December 2008 sub-period. Two differences are visible when they are compared with responses in the first sub-period. First, interest rate shocks are much more important not only for energy prices but also for non-energy prices. It would appear that commodity prices behaved more like price assets in the period preceding the global financial crisis. At the same time, the link running from the real exchange rate to the energy-price rate, and from industrial production to the real interest rate, ceased to be significant, which suggests that financial processes became detached from the real economy. Second, the exchange rate responds positively to shocks in the interest rate. This looks like an anomaly because a higher euro-area interest rate should make the euro stronger and the United States dollar weaker (a negative response), whereas the response functions suggest the opposite.

The January 2009-December 2013 sub-period is a mixture of the features of the previous two. As in the middle period (January 2003December 2008), the interest rate remains unrelated to output shocks, but the real exchange rate does not behave anomalously in response to interest rate shocks. Both commodity prices respond to interest rate shocks and exchange rate shocks as the theory suggests they should. It is interesting to note that non-energy prices respond more strongly to shocks in energy prices than in the other two sub-periods.

\subsection{Variance Decomposition}

The forecast error variance decompositions of changes in commodity price indexes at four time horizons (1, 3, 6 and 12 months), and across three sub-periods, are presented in Tables $5 \mathrm{a}$ and $5 \mathrm{~b}^{2}$. Shocks within their own indexes account for 50\%-85\% of the forecast error variance for both commodity price indexes, though their contribution fell over time.

\footnotetext{
${ }^{2}$ The results for longer time horizons did not differ from those for twelve-month horizons. The variance decompositions for changes in industrial production, the interest rate and the real exchange rate are available on request.
} 
In the first sub-period, interest rate and exchange rate shocks make higher contributions to fluctuations in the energy price index than output shocks. This dominance is even stronger in the middle sub-period when the link to the interest rate was the prevailing feature. The contributions are more balanced in the final sub-period when exchange rate shocks are slightly more dominant.

Table 5a. Variance Decomposition of the Energy Price Index $\triangle P E N$ for each Sub-period

\begin{tabular}{c|c|c|c|c|c|c}
\hline \multirow{2}{*}{ Sub-period } & \multirow{2}{*}{$\begin{array}{c}\text { Horizon } \\
\text { (in months) }\end{array}$} & \multicolumn{5}{|c}{ Shock in: } \\
\cline { 2 - 7 } & $\Delta I P$ & $\Delta I R$ & $\Delta R E X$ & $\Delta P E N$ & $\Delta P N E N$ \\
\hline 1997:1-2002:12 & 1 & 1.99 & 5.01 & 6.39 & 86.61 & 0.00 \\
\cline { 2 - 7 } & 3 & 3.05 & 5.16 & 7.92 & 83.68 & 0.18 \\
\cline { 2 - 7 } & 6 & 3.06 & 5.18 & 7.96 & 83.60 & 0.20 \\
\cline { 2 - 7 } & 12 & 3.06 & 5.18 & 7.96 & 83.59 & 0.20 \\
\hline 2003:1-2008:12 & 1 & 0.06 & 22.88 & 0.21 & 76.85 & 0.00 \\
\cline { 2 - 7 } & 3 & 0.14 & 21.20 & 4.63 & 72.09 & 1.93 \\
\cline { 2 - 7 } & 6 & 0.15 & 21.08 & 4.73 & 71.74 & 2.31 \\
\hline 2009:1-2013:12 & 12 & 0.15 & 21.07 & 4.73 & 71.73 & 2.32 \\
\cline { 2 - 7 } & 3 & 3.78 & 8.97 & 9.30 & 77.96 & 0.00 \\
\cline { 2 - 7 } & 6 & 5.41 & 7.76 & 15.07 & 67.93 & 3.82 \\
\cline { 2 - 7 } & 12 & 5.44 & 8.56 & 15.55 & 66.26 & 4.18 \\
\hline
\end{tabular}

Source: authors' own calculations.

Table 5b. Variance Decomposition of the Non-energy Price Index $\triangle P N E N$ for each Sub-period

\begin{tabular}{c|c|c|c|c|c|c}
\hline \multirow{2}{*}{ Sub-period } & Horizon & \multicolumn{5}{|c}{ Shock in: } \\
\cline { 3 - 7 } & (in months) & $\Delta I P$ & $\Delta I R$ & $\Delta R E X$ & $\Delta P E N$ & $\Delta P N E N$ \\
\hline 1997:1-2002:12 & 1 & 0.05 & 0.00 & 6.54 & 6.96 & 86.44 \\
\cline { 2 - 7 } & 3 & 0.39 & 0.28 & 7.26 & 6.76 & 85.31 \\
\cline { 2 - 7 } & 6 & 0.40 & 0.32 & 7.30 & 6.77 & 85.21 \\
\cline { 2 - 7 } & 12 & 0.40 & 0.32 & 7.30 & 6.77 & 85.21 \\
\hline 2003:1-2008:12 & 1 & 0.61 & 4.62 & 6.22 & 5.95 & 82.59 \\
\cline { 2 - 7 } & 3 & 0.77 & 3.04 & 16.98 & 5.30 & 73.91 \\
\cline { 2 - 7 } & 6 & 0.77 & 2.95 & 17.23 & 5.40 & 73.65 \\
\cline { 2 - 7 } & 12 & 0.77 & 2.94 & 17.24 & 5.40 & 73.64 \\
\hline
\end{tabular}


Table $5 b$ cnt'd

\begin{tabular}{c|c|c|c|c|c|c}
\hline \multirow{2}{*}{ Sub-period } & \multirow{2}{*}{$\begin{array}{c}\text { Horizon } \\
\text { (in months) }\end{array}$} & \multicolumn{5}{|c}{ Shock in: } \\
\cline { 3 - 7 } & & $\Delta I P$ & $\Delta I R$ & $\Delta R E X$ & $\Delta P E N$ & $\Delta P N E N$ \\
\hline 2009:1-2013:12 & 1 & 0.16 & 12.89 & 8.22 & 21.30 & 57.44 \\
\cline { 2 - 7 } & 3 & 1.70 & 10.38 & 17.52 & 17.79 & 52.61 \\
\cline { 2 - 7 } & 6 & 1.76 & 11.54 & 17.57 & 17.36 & 51.77 \\
\cline { 2 - 7 } & 12 & 1.84 & 11.55 & 17.56 & 17.34 & 51.70 \\
\hline
\end{tabular}

Source: authors' own calculations.

The forecast error variance decompositions of changes in the non-energy price index show that the importance of all shocks increased over time. This is especially true for interest rate shocks, whose contribution was initially less than $1 \%$ but increases to more than $10 \%$.

The final observation to make in this section is that the links between commodity prices grew closer as time passed. In this way the contribution of non-energy price shocks to the variance in the energy price index increases from approximately zero to $4 \%$, while the contribution of energy price shocks to the variance in the non-energy price index rises from $7 \%$ to $17 \%$. The closer link could be explained by the rising importance of biofuels in the non-energy price index (see Demirbas 2011) and/or the heightened interest of investors in financial markets for non-energy commodities. The former has the effect of making non-energy commodities similar to energy commodities, while the latter renders them similar to financial assets.

\section{Conclusion}

The euro area is a large open economy whose real and financial developments have the potential to exert a considerable impact on commodity prices. The structural VAR model for three sub-periods has been employed to check whether this relationship holds. The first major finding is that economic activity in the euro area is mostly neutral for commodity prices.

The second major finding is that the same could not be said of the real interest rate and the exchange rate. Energy prices and non-energy prices respond to shocks in the real interest rate in all sub-periods, and the link grows particularly strong in the period preceding the global financial crisis. Real exchange rate shocks gain in importance in the period following the crisis, that is, in the final sub-period of January 2009-December 2013. Even 
though these relationships accord with the standard model of commodity price determination (Frankel \& Rose 2010; Śmiech et al. 2014, for example), the model itself does not imply that financial factors should dominate real processes. However, this is precisely how they behave in the period preceding the global financial crisis.

The third and final major finding is that the relationships between energy commodity prices and non-energy commodity prices became stronger over time. Non-energy commodities, in that they are more sensitive to changes in the interest rate and energy prices, have grown to resemble financial assets.

\section{Bibliography}

Akram, Q. F. (2009) "Commodity Prices, Interest Rates and the Dollar". Energy Economics 31 (6): 838-51.

Alquist, R., Kilian, L. and Vigfusson, R. J. (2011) "Forecasting the Price of Oil" in G. Elliott and A. Timmermann (eds) The Handbook of Economic Forecasting. Second edition. North-Holland, http://dx.doi.org/10.1016/B978-0-444-53683-9.00008-6.

Arora, V. and Tanner, M. (2013) "Do Oil Prices Respond to Real Interest Rates?". Energy Economics 36: 546-55, http://dx.doi.org/10.1016/j.eneco.2012.11.001.

Blanchard, O. J. and Quah, D. (1989) "The Dynamic Effects of Aggregate Demand and Supply Disturbances". American Economic Review 79 (4): 655-73.

Breitung, J., Bruggemann, R. and Lutkepohl, H. (2004) "Structural Vector Autoregressive Modeling and Impulse Response" in H. Lutkepohl and M. Krätzig (eds) Applied Time Series Econometrics. Cambridge: Cambridge University Press, http://dx.doi. org/10.1017/CBO9780511606885.

Davidson, P. (2008) "Crude Oil Prices: 'Market Fundamentals' or Speculation?". Challenge 51 (4): 110-18.

Demirbas, A. (2011) "Competitive Liquid Biofuels from Biomass". Applied Energy 88 (1): 17-28, http://dx.doi.org/10.1016/j.apenergy.2010.07.016.

Dickey, D. A. and Fuller, W. A. (1979) "Distribution of the Estimators for Autoregressive Time Series with a Unit Root". Journal of the American Statistical Association 74 (366a): 427-31, http://dx.doi.org/10.1080/01621459.1979.10482531.

Frankel, J. A. (2008) "The Effect of Monetary Policy on Real Commodity Prices" in J. Y. Campbell (ed.) Asset Prices and Monetary Policy. Chicago: NBER, University of Chicago Press, pp. 291-333.

Frankel, J. A. and Rose, A. K. (2010) "Determinants of Agricultural and Mineral Commodity Prices" in R. Fry, C. Jones and C. Kent (eds) Inflation in an Era of Relative Price Shocks. Sydney: Reserve Bank of Australia.

Hamilton, J. D. (2009) "Causes and Consequences of the Oil Shock of 2007-2008". Brookings Papers on Economic Activity, pp. 215-61.

Johansen, S. and Juselius, K. (1990) "Maximum Likelihood Estimation and Inference on Cointegration - with Applications to the Demand for Money". Oxford Bulletin of Economics and Statistics 52 (2): 169-210. 
Kaufmann, R. K. (2011) "The Role of Market Fundamentals and Speculation in Recent Price Changes for Crude Oil”. Energy Policy 39 (1): 105-15, http://dx.doi.org/10.1016/ j.enpol.2010.09.018.

Kilian, L. (2008) "Exogenous Oil Supply Shocks: How Big Are They and How Much Do They Matter for the US Economy?". The Review of Economics and Statistics 90 (2): 216-40.

Kilian, L. (2009a) "Comment on 'Causes and Consequences of the Oil Shock of 2007-08' by James D. Hamilton”. Brookings Papers on Economic Activity, pp. 267-78.

Kilian, L. (2009b) "Not All Oil Price Shocks Are Alike: Disentangling Demand and Supply Shocks in the Crude Oil Market". The American Economic Review 99: 1053-69, http://dx.doi.org/10.1257/aer.99.3.1053.

Kilian, L. (2010) "Oil Price Shocks, Monetary Policy and Stagflation” in R. Fry, C. Jones and C. Kent (eds) Inflation in an Era of Relative Price Shocks. Sydney: Reserve Bank of Australia.

Krugman, P. (2008) "Commodity Prices". The New York Times, 19 March.

Lescaroux, F. (2009) "On the Excess Co-movement of Commodity Prices - A Note about the Role of Fundamental Factors in Short-run Dynamics". Energy Policy 37 (10): 3906-13, http://dx.doi.org/10.1016/j.enpol.2009.05.013.

Parsons, J. E. (2010) “Black Gold and Fool's Gold: Speculation in the Oil Futures Market". Economia 10 (2): 81-116.

Pindyck, R. S. and Rotemberg, J. J. (1990) “The Excess Co-movement of Commodity Prices". The Economic Journal 100: 1173-87.

Sari, R., Hammoudeh, S. and Soytas, U. (2010) "Dynamics of Oil Price, Precious Metal Prices, and Exchange Rate". Energy Economics 32 (2): 351-62, http://dx.doi. org/10.1016/j.eneco.2009.08.010.

Sims, C.A. (1980) "Macroeconomics and Reality". Econometrica 48: 1-48.

Svensson, L. E. O. (2008) "The Effect of Monetary Policy on Real Commodity Prices: Comment" in J. Y. Campbell (ed.) Asset Prices and Monetary Policy. Chicago: NBER, University of Chicago.

Śmiech, S. and Papież, M. (2013) "Fossil Fuel Prices, Exchange Rate, and Stock Market: A Dynamic Causality Analysis on the European Market”. Economics Letters 118 (1): 199-202, http://dx.doi.org/10.1016/j.econlet.2012.10.010.

Śmiech, S., Papież, M. and Dąbrowski, M. A. (2014) "Energy and Non-energy Commodity Prices and the Eurozone Macroeconomy: A SVAR Approach" in M. Papież and S. Śmiech (eds) Proceedings of the 8th Professor Aleksander Zeliaś International Conference on Modelling and Forecasting of Socio-Economic Phenomena. Kraków: Foundation of the Cracow University of Economics, pp. 165-74.

\section{Abstract}

\section{Wpływ makrogospodarki strefy euro na światowe ceny surowców}

Celem artykułu jest zbadanie wzajemnych powiązań pomiędzy sferą realną i finansową gospodarki strefy euro a cenami surowców energetycznych i nieenergetycznych. Analizy oparto na danych miesięcznych obejmujących okres od stycznia 1997 r. do 
grudnia 2013 r., zaś wzajemne relacje zostały wyjaśnione za pomocą strukturalnego modelu wektorowej autoregresji SVAR. Analiza została przeprowadzona dla trzech podokresów, co miało umożliwić wykrycie potencjalnych zmian relacji. W wyniku badań ustalono, że ceny surowców nie reagowały na wstrząsy aktywności ekonomicznej, natomiast pozostawały pod silnym wpływem procesów finansowych, zwłaszcza w okresie poprzedzającym światowy kryzys finansowy. Badanie wykazało także, że umocniły się relacje pomiędzy cenami surowców energetycznych i nieenergetycznych.

Słowa kluczowe: ceny surowców, sfera realna gospodarki, sfera finansowa, strukturalny model wektorowej autoregresji. 